\title{
Formation of company's economic activity context in the strategic positioning process in emergent environment conditions
}

\author{
Mykhaylo Voynarenko ${ }^{1}$, Kathrin Dumanska, ${ }^{2,}$, and Nataliya Ponomaryova ${ }^{1}$ \\ ${ }^{1}$ Khmelnytsky National University, Department of Accountancy, Audit and Taxation, 11, Instytutska Street, 29000, Khmelnytsky, \\ Ukraine \\ ${ }^{2}$ Khmelnytsky National University, Department of Enterprise Economics and Entrepreneurship, 11, Instytutska Street, 29000, \\ Khmelnytsky, Ukraine
}

\begin{abstract}
Analytical studies of theoretical and methodological aspects of company's strategic positioning influenced by unpredictable factors of changeable environment are examined in the article. Justification of effective choice of strategic position is provided by the concept of formation of company's economic activity context in emergent environment proposed by the authors. Problems of strengthening of company's strategic position in conditions of changeable economic environment with undefined factors can be solved by means of the developed model of company's economic activity context on the basis of methods of mathematical modeling. One of the advantages of the model implementation can be the usage of methodology of company's strategic positioning in economic environment. The model elaborated by the authors implies a set of analytical-calculative aspects of testing and further implementation in strategic management practice. The given article proposes the first conceptual methodological stage of model of company's economic activity context implementation. The obtained results of further adoption can be applied as element of strategic management of vertically integrated companies in conditions of emergent environmental challenges.
\end{abstract}

\section{Introduction}

The current state and contemporary conditions of domestic economy restructuring demand from companies quite new economic approaches. Integration steps of Ukraine into the European Economic Community create new perspectives on the recruitment processes, organization of production, or availability of new ideas and innovative projects. The concept of business development efficiency is also changing and significant role in this process is played by successfully selected strategic position of the company. New approaches towards strategic position selection and evaluation of its effectiveness will increase the flexibility of the company's response to changes in the economic environment, which in their turn will strengthen competitiveness of the company in the market and will allow more effective adaptation to the new conditions of development, updated quality standards and methods of product promotion. It is important to remember that the period of renovation of the economy stimulates companies to maintain their own position in the domestic market, on the one hand, and successful entry into foreign markets, on the other. In order to solve such problems it is necessary to apply conceptually new approaches that can unite both differences and similarities that exist between identification and choosing strategic position as processes of company's management. Such approach, in accordance with author's idea, can be modeling of company's economic activity context considering its emergent aspects.

Strategic positioning problems were proposed and discussed by different prominent economists and their theoretical view points and practical explorations are of valuable importance for further researches and supporters.

The research of the effectiveness of company's strategic positioning was initiated by I. Ansoff in his work "New corporate strategy" [1]. Being one of the representatives and supporters of systematization approach in company's strategic development concept and founder of the "school of planning", Ansoff, applied his systematic approach of corporate strategy shaping and company's strategic positioning, which in the 60s has became an innovation in the processes of corporate management [2].

One of the founders of the "school of design", professor of the Harvard Business School, K. Andrew, in his work "The Concept of Corporate Strategy" (1965) provided quite innovative interpretation of the assessment of company's strategic positioning, which in his view should assess "... such kind of business, within which the company can compete due to such stages of concentration of its resources that allow company to transform its abilities into competitive advantages" [3].

* Corresponding author: Dukatos2020@bigmir.net 
J. March, the founder and ideological leader of the "school of learning", and prominent representative of the behaviorists' approach, in his work "Behaviorists' Theory of the Firm" proposes to assess the corporate strategy as "... an internal mechanism that determines the company's behavior in the market during the period of competition concerning necessary resources ..." [4], which transforms the company's strategy from managerial to adaptive leverage of strategic positioning.

Significant contribution to the development of competitive direction of the behavioural approach and the "school of positioning" was made by Harvard University Professor M. Porter in the 70's-80's of the 20th century through the development and implementation into the activity of more than 100 American companies the latest aspects of strategic modeling by such as general strategic model (it is often mentioned by economists as "M. Porter's strategic model"), the "chain of values" method, the methodology of company's strategic positioning [5]. From the point of view of progress, in changing of approaches to assessing the company's strategic positioning, we can observe a quite clear change in Professor Porter's views in his earlier and modern works. And if the "early" Porter has fully emphasized the leading role of the corporate strategy in the process of effective company's positioning in competitive environment, Porter of the later period defends rather an opposite position, which destroys the standard methodological approaches to the assessment of adaptive processes of the company. In his works of the 80 's- -90 's, M. Porter has paid maximum attention to the individualization of the corporate strategy of each individual company. He affirming that strategy is not only a leverage of successful company's positioning, but the basis of its competitive advantages and victories: "The strategy is aimed at searching for development of an individual and unique way to compete not only because it is the most versatile way for competition, but also because it allows a company to build the activity of its price (production) chain individually and uniquely. Strategy is the development of a special type of value (commodity), but not an attempt to make the same kind of value (commodity) but only better one" [6]. M. Porter, as the initiator of the creation of economic clusters and the founder of the nonprofit organization of the United States, "The Initiative for a Competitive Inner City" (founded in 1994 by Harvard Business School Professor Michael Porter) proved that the competitiveness and adaptability of the company is determined by the competitiveness and adaptability of its economic environment, and in its turn, depends on the basic conditions and competition within the cluster (http://icic.org/member/professor-michael-eporter).

Professor E. Utkin, one of the supporters of behavioural trend, became a bright representative in the field of strategic and crisis management companies in the 90's-2000's [7]. The basis of proposed methodology in the field of evaluation of company's strategic positioning is the application of the basic component of corporate management - the motivation of each individual employee of the team in different ways according to psychological peculiarities.

At the beginning of the XXI century many foreign of domestic economists specializing in the study of multilevel issues of company's strategic positioning supported and followed the world economic opinion regarding the assessment of the effectiveness of company's strategic adaptation and positioning in a wide range of their activities. The authors of the scientific works research problems of positioning and adaptation of industrial companies, trade networks, advertising agencies and the adequacy of their strategies in a changing environment with flexible competition. In this context, Professor A. Gradov, as one of the supporters of the competitive approach in the study of strategic activity of business entities, in his work "Strategy firm effectiveness" [8] offers a specific generalized approach towards assessing the strategy's effectiveness and positioning of the firm based on the integrated business theory expressed by the scheme of assessing the effectiveness of the company's positioning and development.

Contemporary researchers in the field of strategic aspects of the company's economic activity context formation pay special attention on the consideration of the processes of choosing strategic position, based on behavioural and emergent approaches. For example, H. Greve and G. Gavetti [9], in the framework of the behavioural approach, propose modern methods for evaluating the effectiveness of company's strategy from the point of view of competitiveness and psychological assessment of activities of the customer. P. Beamish and N. Lupton [10] in their critical analysis of Andrews' research focus on the transition of modern companies from the internal concentration of competitive resources to the exit beyond the geographical boundaries of countries and reorientation to global international level of competitive opportunities.

M. Augier [11] in his turn, proposes a number of modern methods for evaluation the process of company's adaptability in the market and the basis of such methods can be considered as the classical behavioural approach.

The concept of an emergent strategy and an emergent strategic approach to management in accordance with the classification of H. Mintzberg [12] has appeared in the "school of learning", where the principle of emergent strategy is based on the adoption of flexible intellectual decisions of a company manager in crisis situations.

Authors' approach towards strategic positioning can be revealed in the process of business capitalization modeling and formation of company's alternative strategic position in economic environment [13] and estimation of positioning effectiveness of energetic companies in conditions of European integration [14]. Researching in the field of transformation of socialeconomic system in conditions of global integration was accomplished from the point of view of conceptual basis of economic emergent processes [15]. 


\section{Methodology of researching}

The concept of emergency reflects peculiarities of company's activities in conditions of unpredicted appearance of environmental challenges that are characteristic for unstable politico-economical, social, legislative and other factors. Unpredicted environmental changes, in their turn, can lead to company's emergent reactions in the form of concentration of principally new strategic resources and possibilities in activity in conditions of unstable environment. Methodological apparatus of applied mathematical methods can provide vide possibilities for reflection and analysis of key aspects of company's emergent reactions in economic environment.

On the basic of mathematical modeling methodology the proposed model of company's economic activity context was formed and presented by means of indirectly proportional semi-logarithmic dependence of duration of the alternative strategy formation (productive feature of the environment) from the conjuncture of its economic environment (factor of nature of the environment) and was reflected by vectors' system.

\section{Results}

\subsection{Concept of formation of company's economic activity context in emergent environment}

Management of modern industrial companies provides a clear modeling of their economic activity context. The construction of a clearly structured and, at the same time, ramified model of situational analysis of the environment of an economic entity provides an opportunity for its effective strategic positioning and adaptation to existing economic, political, social, natural and other conditions of existence. However, the rate of change in external as well as internal factors of influence has been so high in recent years that companies do not have any time or opportunity to react quickly and construct adequate development models even for the next six months. Possibility of preventing significant losses of the company in a similar situation gives a successful choice of strategic position, which is preceded by a thorough analysis of the internal, external, direct and market environment, and that can be resulted in forecasting the use of the necessary resources, costs and profits. In bits turn, the choice of effective strategic position of the company depends on the factors of its environment. That is why the authors have selected an emergent research direction, which provides "operative mobilization of fundamentally new qualities" [16] of a changing environment and reveals the peculiarities of its influence on the company's activities.

According to the authors' explorations, it is advisable to consider the emergence concept factors of company's environment in the direction of emergent strategic management that ensures spontaneous and flexible adaptation to the conditions of external environment and promotes a timely response to processes of bifurcation, nonlinear changes in the trends of external indicators. One of the examples of manifestation of the emergence strategic management concept is the company's micro strategy [17], focused on short-term implementation with the achievement of short-term goals that can ensure the flexibility and speed of the company's response to the influence of environmental factors. On the one hand, emergence concept characterizes peculiarities of company's activities in conditions of contemporary Ukrainian economy with its emergent challengers that can appear on the side of social policy, legislation, pricing, tariff formation and other environmental factors. At the same time, on the other hand, emergency creates principally new reactions on environmental "irritants" that can stimulate company in searching new possibilities of surviving and allow its further development. Thus emergence concept simultaneously discloses the essence of company's economic activity context and provides possibilities of effective reactions on various environmental changes.

Taking into consideration authors viewpoint it can be stressed that well-formed economic activity context provides the company with the opportunity to effectively predict the duration of strategic adaptation in a changing economic environment and tendencies for further development within a certain time lag according to corporate strategy. Based on the information on the state of factor and performance indicators of the economic environment in the form of economic indicators of the context of economic activity, the company is able to forecast its competitive position in the market, which, in turn, allows us to form a strategic direction of development and to determine a convenient strategic position.

Effective strategic positioning of company in the market provides high level of its competitiveness, especially in conditions of dynamic economic environment [18]. Successful strategic position, fresh commercial ideas and various market advantages allow companies maintain favorable conditions for effective business activities and they can easily dictate their rules to partners and competitors. That is why modern companies consider effective strategic positioning to be one of the major aspects of corporative strategy formation. One of the most important factors of a company's strategic position selection is the successful formation of the context of its economic activity. The "context of economic activity" is explained by the authors as "the space of parameters of the economic environment in which it is possible to trace and predict the dynamics of changes in conditions of the company, the dynamics of changes in factor and indicators performance of the economic environment, presented in the form of economic indicators, and the duration of the process of strategic adaptation in given conditions" [19].

The concept of formation of company's economic activity context, according to the authors, is based on a number of such processes as:

- formulating company goals;

- studying economic environment and level of factors of its emergence; 
- determination of critical elements of a market environment and internal environment that can affect the company's ability to achieve its goals;

- forecasting of company's interaction with economic environment in future.

The question of company's influence on the economic activity context and its contextual dependence is controversial, as the impact of one or another economic force depends on situational changes in the country's economy that can increase or decrease the company's value in domestic or foreign markets. However, the predicted formation of the context of its economic activity provides the company with the ability to succeed in such economic situations that are not yet come, but successfully may be fulfilled. Based on the experience of well-known world companies [20], authors propose to form the context of the economic activity of the investigated companies on the basis of two stages. The first stage, the assessment of the economic environment influence on the company's activity, is carried out by using such methods as the method of determining the degree of influence of factors of the economic environment on the company's activities, the SWOT-method, the method of forecasting of strategic changes in the components of the company's economic environment, and the method of identifying the potential of internal capabilities of enterprises and companies. The second stage, an assessment of the strategic adaptation of the company, is carried out by using the method of determining the strategic adaptation of the company. Thus, the results of the process of assessing the impact of the economic environment on the company's activities and the process of assessing its strategic adaptation can form the context of the company's economic activity within its framework.

The ultimate goal of company's economic environment forming is to determine its effective strategic position in conditions emergent influence of external factors, for the visual representation of the situation, thus the authors have chosen precisely such like mathematical models that take into account the plurality and uncertainty of the environment. As a result of the combination of semi-logarithmic dependence on the theory of sets, the authors formed the model of company's economic activity context that became the basis for choosing a strategic position under the conditions of the emergent environment.

The proposed model takes the first stage of elaboration and has a theoretical-methodological character. In authors idea the model of company's economic activity context implementation implies the following stages:

1. Conceptual justification of model's necessity in conditions of company's emergent economic environment

2. Analysis of current indicators of existing corporative strategies of vertically integrated Ukrainian industrial companies.

3. Comparative analysis of current and predictable indicators company's economic environment conjuncture and justification of its percentage proportion influenced by emergent factors.
4. Elaboration of alternative companies' corporative strategies and effective strategic position choice considering influence of company's economic environment factors.

Quite often in the process of economic researches scientists may come across problems of shortage of results visibility and consequently the level of readers' perception of proposed material can be greatly decreased. That is why authors propose one of the methods of visibility with the help of which the model of company's economic activity context can be depicted mathematically in the form of semi-logarithmic dependence of the duration of company's strategic adaptation of the economic environment conjunction. In our opinion, semi-logarithmic dependence gives possibility of a generalized description of the company's dependence on the environment in which it operates and attempts to adapt adequately, developing the appropriate options for a development strategy. This dependence reveals characteristic changes in the company's strategic position during the time with the instability of economic indicators of its environment [21]. Within the company's economic activity context it is possible to trace and predict dynamics of changes in the results of its activities in accordance with the economic environment conjuncture, the duration of strategic adaptation and other factor and performance characteristics of the environment, presented in the form of economic indicators that have direct and indirect influence on company's activities. Under the definition of "economic environment conjuncture" [22] authors mean "the total influence of a number of indicators that are characteristic of a qualitative description of changes impact in the economic environment on the duration of the company's strategic positioning". In its turn, under the duration of the company's strategic positioning, we can understand the time that is necessary for the development of alternative strategy options.

\subsection{Modelling of company's economic activity context}

Authors propose to establish the suitable model of company's economic activity context (Fig. 1.) in following form, where main parameters of the model are $\mathrm{Y}$ (as a duration of the alternative strategy formation) and $\mathrm{X}$ (as an economic environment conjuncture).

The model of company's economic activity context, in accordance with authors' idea, can be expressed by indirectly proportional semi-logarithmic dependence of duration of the alternative strategy formation (productive feature of the environment) from the conjuncture of its economic environment (factor of nature of the environment). For example, according to this model, the change in the economic environment conjuncture by $10 \%$ compared with its current value will change the duration of the alternative strategy formation by $15 \%$, and the change in the corresponding indicator by $10 \%$ in condition of changed economic environment determines changes of the corresponding indicator by $5 \%$. 


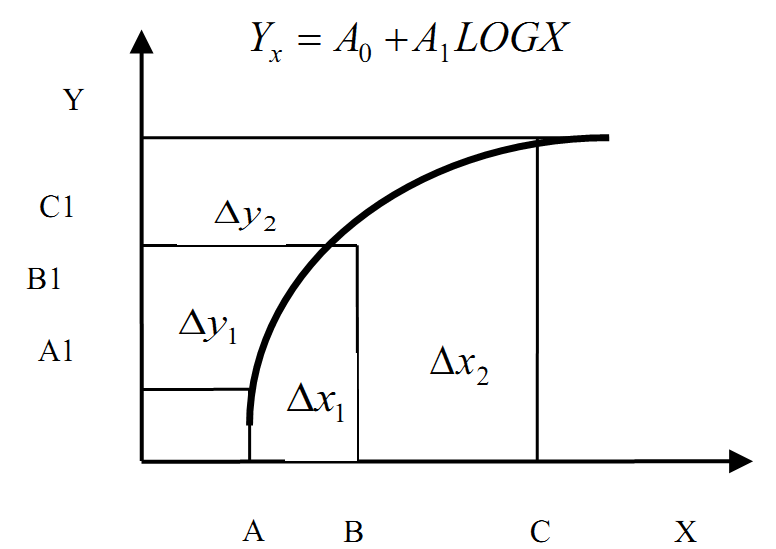

Fig. 1. The model of company's economic activity context.

So, it is important to underline the necessity of depicting economic environment of the company and its components within company's economic activity context as vectors system in accordance with the set theory is quite obvious. And it is the set theory that reflects multiple opportunities of changeability of unpredictable situations.

It the researching process such parameters of vectors system of companies' economic environment, as: IE internal environment, DE - direct environment, EE external environment, $\mathrm{ME}$ - market environment, $\mathrm{EcE}$ economic environment, where proposed by the authors.

The obtained vectors system of company's economic environment is represented below:

$$
\vec{I} E=\left\{a_{1}, a_{2}, \ldots, a_{i}\right\}
$$

where $i-$ number of parameters of the internal environment;

$$
\vec{D} I=\left\{b_{1}, b_{2}, \ldots, b_{d}\right\}
$$

where $d-$ number of parameters of the direct environment;

$$
\vec{E} E=\left\{c_{1}, c_{2}, \ldots, c_{e}\right\}
$$

where $e-$ number of parameters of the external environment;

$$
\vec{M} E=\left\{d_{1}, d_{2}, \ldots, d_{m}\right\}
$$

where $m$ - number of parameters of the market environment;

$$
\vec{E} c E=\left\{f_{1}, f_{2}, \ldots f_{e_{c}}\right\}
$$

where $e c$ - number of parameters of the economic environment.

In frame of mathematic modeling the set theory suggests not only vector reflection data but matrix as well. With the help of matrix it'll be possible to calculate current and predictive range of situational data. That is why, the authors have elaborated the matrix for determining the influence of current and emergent factors on company's activity. Consequently, we decided to represent the company's economic environment according to set theory by the formula 1 , as:

$$
\left\{\begin{array}{l}
\forall{ }_{d} \in D E \rightarrow m \in \vec{M} E \\
\forall e \in E E \rightarrow m \in \vec{M} E \\
M E=E E \bigcap D E \\
\forall_{i} \in I E \rightarrow e_{c} \in \vec{E}_{c} E \\
\forall d \in D E \rightarrow e_{c} \in \vec{E}_{c} E \\
\forall e \in E E \rightarrow e_{c} \in \vec{E}_{c} E \\
\forall_{m} \in M E \rightarrow e_{c} \in \vec{E}_{c} E
\end{array}\right\} \Rightarrow \vec{E}_{c} E=I E \bigcap M E
$$

On the basis of set theory we propose to depict economic environment with the help of Eulerian circles as illustration of our conceptual approach that are shown in Fig. 2.

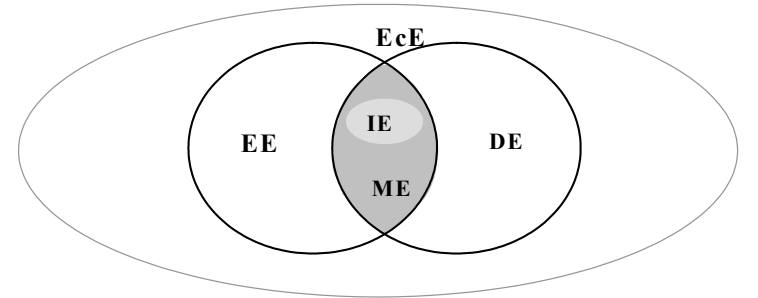

Fig. 2. The scheme of company's positioning in economic environment context based set theory.

Taking into consideration authors' opinion, the proposed model of company's economic activity context, based on mathematic models, can be an easy and suitable way for predicting future changes of company's economic environment.

\subsection{Company's positioning in the economic environment context}

The essence of the process of choosing company's strategic position is to find and specify the strategic direction of development in frame of which managers can develop a corporate strategy based on the data obtained on the state of the economic environment. Such data include: existing and prospective potential of company, the level of strategic adaptation, general level of strategic business units' (SBU) [23] prospects as well as competitive status and competitive position of company in the market. In particular, for industrial enterprises, it is proposed to highlight progressive and regressive directions of strategy development. Progressive directions cover diversification, integration, and concentration processes, while regressive trends cover processes of reduction, elimination. The progressive/regressive directions of the development of company's industrial strategy is proposed to determine boundaries of the model of company's economic activity context (according to its competitive position) depending on state of factors of economic activity context, in particular, the economic environment conditions for the 
period of strategy formation, the level of strategic potential of success and competitive status.

Effective choice of company's strategic position or its positioning in the market space is the key to company's success in the market. The well-grounded strategic position allows an entity to occupy an appropriate market position or market niche, which provides possibility of successful adaptation within the direct environment, market environment and economic environment as a whole.

The process of company's positioning in economic environment context, in our opinion, can be represented in the form of three main processes, such as:

- formation and evaluation of effectiveness of strategic business units' (SBU) activity;

- determination of the strategic success potential of company;

- estimation of the competitive status.

Company's positioning in the economic environment context involves the determination of its location relatively to the competitive position of its competitors. Such world known consulting companies, as the Boston Advisory Group (1968-1972), GE/McKinsey \& Co (1971-1973), together with General Electric, Arthur D. Little's Company (1979-1980), as well as the BritishHolland Chemical Company Shell (1975) have already developed series of classic models of strategic analysis and planning of corporate activities, these models are based on comprehensive analysis of the economic environment, creation of future forecasting development models and collaboration of a number of alternative company's strategies taking into account environmental emergency. The economic value and usefulness of applying classical models in the process of selecting and shaping strategic position of the company lie in the methodological and mathematical apparatus especially reacted for such lake models, which provide analysis and processing of strategic information and adoption of appropriate managerial decisions. Strategic information encompasses processes of the company's operation in present and in future in the directions of all possible aspects of the activities, taking into consideration peculiarities of adaptation in the economic activity context. The strategic information collected is used by the company's management to develop a corporate strategy.

In particular, as the Ukrainian industrial companies are concerned, the authors propose strategic positioning based on the classical model of strategic analysis and planning of Shell Directional Policy Matrix (Shell/DPM). The Shell/DPM model, in our opinion, is quite optimal for determining the company's competitive position in the context of the economic environment due to its orientation towards application in vertically integrated companies. Vertical integration is widespread in domestic companies, especially in the brunch of mechanical engineering, because all activities (business) are based on the leading technological line for the production of the dominant type (group) of products, which is aimed at only one segment of the market. In such cases when the company also produces goods for different segments of the market, its production is carried out by units of one company, i.e., one company provides operation of several strategic business units.

In conclusion, we can note that in the process of research of proposed topic certain requirements that should be observed in case of choosing and forming a strategic position of the company where formulated by the authors. These requirements encompass the following spheres of managerial activity:

- formation of a strategic direction on the basis of analysis of the determined goals;

- establishment of harmonious connection between the chosen strategic direction and the state of economic environment factors;

- ensuring a high level of flexibility and adaptability of selected strategic direction in accordance with the main parameters of the environmental assessment (parameters of the economic environment modeling and modeling of the company's competitive position).

Contemporary situation and current conditions of the Ukrainian economy are rather specific and complicated, on the one hand, the development of domestic companies is one of the major and primary tasks of economic development, and on the other hand, companies are faced with massive pressure of fleeting changes in the legislative framework and socio-political conditions that destabilize their work and deprive them of opportunities for successful development. But such like economic situation gives companies an invaluable experience of practical learning to survive and can force them to mobilize their opportunities for the development in the context of rapid changes. Summarizing the diversity of theoretical and practical view points on the topic, we can conclude that in this particular situation, the proposed model of the company's economic activity context provides business with ability to assess the impact of an incalculable number of the economic environment factors and helps to obtain the most reliable evaluation of the adaptive capabilities of the company in existed economic conditions.

\section{Conclusions}

The mechanism of strategic management of the company provides such conditions of its functioning that ensure stability of the development and the ability to respond flexibly to the challenges of the external environment. That is why the variability of the company's development should be considered at the level of strategic management, including the hierarchy of corporate strategy objectives such as ability for adaptation to predict and reflect unpredictable changes in the economic environment. The proposed model of company's economic activity context gives an opportunity to fulfill an effective choice of company's strategic position in conditions of emergent environment factors and to predict favorable conditions for development and functioning in the market. It is important to recognize that this model makes it possible to know where the company has been, where it is now and where it is going to. This is especially valuable because it provides the company with possibility of more 
flexible strategic management as well as stable enduring resistance to adverse impact of the environment.

The problem of effective development of diversified companies is of great importance, as the positive general economic effect in a particular industry and economy as a whole can be achieved only through the successful functioning of each separate structural unit in the integrated international economic system. In its turn, the high level of instability of the company's economic environment as an economic structural unit of dramatically increases the importance of strategic positioning, because such a process allows to coordinate company's activities in different functional areas, mobilize resources and if necessary can direct company to the solution of internal and external problems. As it can be traced, the effective strategic positioning ensures the formation of adoptive and flexible context of company's economic activity in emergent environment conditions.

\section{References}

1. Ansoff, H.I.: The New Corporate Strategy. Wiley, New York (1988)

2. Ansoff, H.I.: Business Strategy. Penguin Books, Harmondsworth (1969)

3. Andrews, K.R.: The Concept of Corporate Strategy. Dow Jones-Irwin Inc, Homewood, Illinois (1971)

4. Cyert, R.K., March, J.G.: A Behavioural Theory of the Firm. Macmillian, London (1979)

5. Porter, M.E.: Competitive Advantage: Creating and Sustaining Superior Perfomance. Free Press, New York (1985)

6. Hodgetts, R.M.: A Conversation with Michael E. Porter: a 'significant extension' toward operational improvement and positioning. Organizational Dynamic. 7, 24 (1999)

7. Utkin, E.A., Morozova, G.I., Morozova, N.I.: Innovatsionnyy menedzhment. Akalis, Moskva (2002)

8. Gradov, A.P.: Effektivnost strategii firmy. Spets. Lit, Sankt-Peterburg (2007)

9. Gavetti, G., Greve, H.R., Levinthal, D.A., Ocasio, W.: The behavioural theory of the firm: assesment and prospects. The Academy of Management Annals. $\quad$ 6(1), $\quad 1-40 \quad$ (2012). doi:10.1080/19416520.2012.656841

10. Beamish, P.W., Lupton N.C.: Cooperative strategies in international business and management: reflections on the past 50 years and future directions. Journal of World Business. 51(1), 163175 (2016). doi:10.1016/j.jwb.2015.08.013

11. Augier, M.: Behavioral theory of the firm: hopes for the past; lessons from the future. Management. 16(5), 636-652 (2013). doi:10.3917/mana.165.0636

12. Mintzberg, H.: The strategy concept II: another look at why organizations need strategies. California Management Review. 30(1), 25-32 (1987)
13. Asaul, A.N., Voynarenko, M.P, Skorobogata, L.V.: Transformation of business capitalization model within the knowledge economy. Actual Problems of Economics. 11(161), 8-16 (2014)

14. Voynarenko, M.P., Mykolyuk, O.A.: Strategic energy security outlook formation of Ukraine under European integration process. Scientific Bulletin Polissia. 3(11), 29-37 (2017)

15. Voinarenko, M.P, Honchar, O.I.: Transformatsiia sotsialno-ekonomichnykh system za umov intehratsiinykh peretvoren. Zhurnal Yevropeiskoi ekonomiky. 17(2), 225-243 (2018)

16. Muratov, A.S., Povarich, P.L.: Sinergizm i emerdzhentnost: genezis ikh garmonizatsii v ekonomike i upravlenii. Vestnik KemGU, 1(49), 271-275 (2012)

17. Khalkvat, K.: Kontseptsiya strategicheskogo upravleniya razvitiyem predpriyatiy. Menedzher. 2(68), 155-162 (2014)

18. Ansoff, H.I., Kipley, D., Lewis, A.O., HelmStevens, R., Ansoff, R.: Implanting Strategic Management. Wiley, New York (2018)

19. Dumanska, K.S.: Mekhanizm rozrobky stratehii promyslovoho pidpryiemstva na osnovi systemnoho pidkhodu. FOP Melnyk, Khmelnytski (2015)

20. Voropaev, V., Gelrud, Y.D., Klimenko, O.: Who manages what? Project management for different stakeholders. Procedia Social and Behavioral Sciences. 226, 478-485 (2016) doi:10.1016/j.sbspro.2016.06.214

21. Khanfar, A.A., Mavi, R.K., Jie, F.: Prioritizing critical failure factors of IT projects with fuzzy analytic hierarchy process. In: Proceeding of the International Conference on Mathematics, Engineering and Industrial Applications. AIP Conference Proceedings. 2013, 1, 020058 (2018). doi:10.1063/1.5054257

22. Ponomaryova, N.A.: Premises for creation and development of innovation cluster structures under conditions of institutional economic development. In: Musial, J. (ed.). Actual Problems of Modern Sciense, vol. 1, pp. 110-119. University of Science and Technology, Bydgoszcz (2017)

23. Ansoff, H.I.: Strategic Management. Wiley, New York (2007) 